Omni-Akuatika, 17 (1): 37 - 45, 2021
ISSN: 1858-3873 print / 2476-9347 online
Research Article
journal homepage: http://ojs.omniakuatika.net

\title{
Effect of fish meal replacement with lentil seed (Lens culinaris) in common carp (Cyprinus carpio) L. diet
}

\author{
Nasreen M. Abdulrahman ${ }^{1}$, Vian M. Ahmad ${ }^{2}$, Bakhan R. Hassan ${ }^{2}$, Zaweta S. Abdulla ${ }^{2}$, Derin O. \\ Muhammed-Ramzi ${ }^{1}$, Hevar A. Hama-Salih ${ }^{3}$, Hemin N. Mohammed ${ }^{2}$ \\ ${ }^{1}$ College of veterinary medicine, university of Sulaimani, Iraq \\ ${ }^{2}$ Department of Animal Science, College of Agricultural Engineering Sciences, University of Sulaimani, Iraq \\ ${ }^{3}$ Municipality of Sulaimani, directorate of gardeners, Sulaimani, Iraq \\ *Corresponding author: bakhan.hassan@univsul.edu.iq
}

Received 17 May 2021; Accepted 23 June 2021; Available online 30 June 2021

\begin{abstract}
The aim of this study was to see how replacing fish meal with lentil seeds (LS) as an alternative plant protein source in diets for common carp Cyprinus carpio affected growth performance, feed consumption, and the composition of the fish's proximate carcass. The fish (100-106 g mean initial weight) were fed $0 \%$ (LS0), $5 \%$ (LS5), 10\% (LS10), 15\% (LS15) and 20\% (LS20) of Lentil seed protein for 10 weeks. With increasing fishmeal replacement with lentil seed in the fish diet, there was a significant $(p<0.05)$ increase in weight gain, relative and specific growth rate. T5 $(20 \% \mathrm{LS})$ had a significantly $(p<0.05)$ higher feed efficiency ratio and protein efficiency ratio than the other treated groups. There were no significant $(p<0.05)$ differences in the mean values of proximate composition of fish fillets, such as moisture, crude protein, crude lipid and ash. Finally, no significant differences in muscle ratio (weight without viscera vs. weight without viscera \& head) were found. The current study found that lentil seed can replace $20 \%$ of dietary fish meal in common carp diets for better growth.
\end{abstract}

Keywords: lentil seed, fish meal, common carp, growth performance and feed utilization.

\section{ABSTRAK}

Tujuan dari penelitian ini adalah untuk melihat bagaimana penggantian tepung ikan dengan biji lentil (LS) sebagai sumber protein nabati alternatif dalam pakan ikan mas Cyprinus carpio mempengaruhi kinerja pertumbuhan, konsumsi pakan, dan komposisi karkas proksimat. Ikan (berat awal rata-rata $100-106$ g) diberi makan 0\% (LS0), 5\% (LS5), 10\% (LS10), 15\% (LS15) dan 20\% (LS20) protein biji Lentil selama 10 minggu. Dengan meningkatnya penggantian biji lentil dengan tepung ikan dalam pakan ikan, terjadi peningkatan berat badan, laju pertumbuhan relatif dan spesifik yang signifikan $(p<0,05)$. T5 (20\% LS) memiliki rasio efisiensi pakan dan efisiensi protein yang lebih tinggi secara signifikan $(p<0,05)$ dibandingkan dengan kelompok perlakuan lainnya. Tidak ada perbedaan yang signifikan $(p<0,05)$ dalam nilai rata-rata komposisi proksimat fillet ikan, seperti kadar air, protein kasar, lemak kasar dan abu. Akhirnya, tidak ada perbedaan signifikan dalam rasio otot (berat tanpa jeroan vs berat tanpa jeroan \& kepala) ditemukan. Studi saat ini menemukan bahwa biji lentil dapat menggantikan $20 \%$ makanan ikan dalam makanan ikan mas untuk pertumbuhan yang lebih baik.

Kata kunci: biji lentil, tepung ikan, ikan mas, performa pertumbuhan dan pemanfaatan pakan.

\section{Introduction}

For several fish species, fishmeal is considered the gold standard nutritional protein source. Its production is dependent on noncommercial wild marine fish (Hertrampf and Piedad-Pascual, 2012). However, it is now considered both economically and ecologically unsustainable, and the aquaculture industry is under social and economic strain to find substitute proteins (Turchini et al., 2019).

In aquafeeds, plant proteins are the most common fishmeal replacements. They are costeffective, and they are often preferred due to market perceptions of the use of terrestrial animal by-products for fish feeding (Gajardo et al., 2017; Shepherd et al., 2017). Proteins are highly digestible for fish in most properly 
processed feedstuffs, protein digestion coefficients in protein-rich feedstuffs are typically in the range of 75 to $95 \%$, and protein digestibility tends to be depressed as dietary carbohydrate concentration increases (Hemre et al., 2002).

Cyprinus carpio Linnaeus, 1758 which has been a common aquaculture fish for more than 2,000 years, is one of the world's most commercially valuable and widely cultivated freshwater fish, contributing to $11 \%$ of the world's total production of freshwater aquaculture (FAO, 2010). More than $90 \%$ of this production comes from Asia, where different pond aquaculture systems cultivate common carp. Similarly, in response to changing food resources, common carp can alter its food preference and conduct (Rahman et al., 2008).

Lentil has been referred to colloquially as "Poor man's meat", as it is a rich source of nutrients, composed of $60 \%-67 \%$ carbohydrate, $20 \%-36 \%$ protein, $<4 \%$ lipid, and $2 \%-3 \%$ ash on a dry basis (Bhatty, 1988). This study aimed to assess the use of lentil seeds as a partial substitute for fish meal protein in common carp diets and evaluate the effect of feed containing different lentil seed ratios on growth, feed utilization and proximate carcass composition in common carp.

\section{Materials and Methods}

\subsection{Experimental Fish}

The experiment was performed on 150 common carp. C. carpio L. was brought from local fish ponds in Peramagrun/ Sulaimani/ Iraq. The fish weighed between (100-106 g), preacclimation and feeding of commercial pellets were carried out for 30 days before the actual feeding trials.

\subsection{Experimental Procedure}

In this experiment, fifteen plastic tanks $(100 \mathrm{~L})$ were used for five treatments of 3 replicates each; ten fish were stocked with each replica for 70 days. Using Chinese air compressors, Hailea ACO-318, proper continuous aeration was applied to each tank. To decrease the variations between treatments, the replicates were randomly positioned. To extract residual feed and feces from the system, regular cleaning by siphoning process was applied. Treatments were as follows:

T1: $0 \%$ lentil seed replaced with fishmeal (control diet).

T2: $5 \%$ lentil seed replaced with fishmeal

T3: $10 \%$ lentil seed replaced with fishmeal

T4: $15 \%$ lentil seed replaced with fishmeal
T5: $20 \%$ lentil seed replaced with fishmeal

\subsection{Diet Formulation}

Experimental diets contained standard ingredients (soya bean meal, yellow corn, barley, wheat bran and lentil seed) found in the city markets of Sulaimani, enriched with the lentil seed levels. Preparing five different diets each contains the desired lentil level as described in table 1 . The ingredients items were mixed with water to obtain a dough, then using electrical mincer for pelleting by Kenwood Multiprocessors. Room temperature drying and crushing were used to extract fine particles. Twice daily feeding at 10:00 a.m. and 3:00 p.m. for a bodyweight of $3 \%$ was carried out.

\subsection{Growth and Feed Utilization Parameters}

On all replicates, the fish were weighed together (g) every 2 weeks. Every replicate's feed intake was then recalculated.

- Weight gain $(\mathrm{g})=\mathrm{W} 2-\mathrm{W} 1$ $\mathrm{W}_{2}$ : Fish weight at the end of the experiment

$\mathrm{W}_{1}$ : Fish weight at the beginning of the experiment

- Daily weight gain (DWG) $(\mathrm{g})=\mathrm{W}_{2}-\mathrm{W}_{1} /$ $T$

$\mathrm{T}$ : the time between $\mathrm{W} 2$ and $\mathrm{W} 1$

- Relative growth rate (RGR \%) $=W_{2}-W_{1} /$ $\mathrm{W}_{1} \times 100$ (Brown, 1957)

- Specific growth rate (SGR) \% $=(\mathrm{Ln} W 2$ - Ln W1)/ T) x 100 (Lagler, 1956)

- Survival rate $(\%)=100$ (final fish number / initial fish number)

- Feed conversion ratio $(\mathrm{FCR})=$ Total feed fed (g)/ Total wet weight gain (g) (Uten, 1978)

- Feed efficiency ratio $(F E R)=$ Total weight gain (g)/ Total feed fed (g) (Uten, 1978)

- Protein efficiency ratio $(P E R)=$ Total wet weight gain (g)/ Amount of protein fed (g) (Uten, 1978)

\subsection{Proximate Composition}

Moisture content was determined as weight loss after samples were dried in the convection oven at $105^{\circ} \mathrm{C}$ until the weight was stabilized (Folch et al., 1957). Protein content was determined according to the Association of Official Analytical Chemists AOAC (2005) by using the Micro Kejldahal method and was calculated as follows: Protein $\%=$ nitrogen $\times 6.25$. 
Table 1. Percentage of experimental diet components for fish and chemical composition of the different types of diet by NRC (1993)

\begin{tabular}{|c|c|c|c|c|c|c|}
\hline Ingredients & Ratio\% & $\begin{array}{c}\text { Crude } \\
\text { Protein } \\
\%\end{array}$ & $\underset{\%}{\text { Crude Fat }}$ & $\begin{array}{c}\text { Dry Matter } \\
\%\end{array}$ & $\begin{array}{c}\text { Crude } \\
\text { Fiber } \\
\%\end{array}$ & $\begin{array}{c}\text { Energy } \\
\text { Kcal/ } \\
\text { kg }\end{array}$ \\
\hline Soya bean meal & 35 & 48 & 1.1 & 89 & 7 & 2230 \\
\hline Yellow corn & 13 & 8.9 & 3.6 & 89 & 2.2 & 3400 \\
\hline Barley & 15 & 11 & 1.9 & 89 & 5.5 & 2640 \\
\hline Wheat bran & 20 & 15.7 & 4 & 89 & 11 & 1300 \\
\hline Fish meal & 15 & 65.4 & 5.6 & 90.5 & 0.00 & 1290 \\
\hline Vit $+\min$ & 2 & --- & --- & --- & --- & --- \\
\hline lentil seed* & --- & 25 & 1 & 93 & 11 & 1480 \\
\hline Total & 100 & & & & & \\
\hline Crude protein (\%) & 28.46 & & & & & \\
\hline Crude fat (\%) & 3.29 & & & & & \\
\hline
\end{tabular}

The crude lipid of fish meat was determined according to Folch et al. (1957). The percentage of lipids was determined according to the following formula: Lipid \% = (weigh of extract / weigh of sample) $\times 100$.

Ash content was determined according to the AOAC (2005) method by taking a sample of a known weight of fish flesh and placed in a muffle furnace at $550 \stackrel{\circ}{\circ}$ for 16 hours and then the ash percent was determined as follows: Ash $\%=(\mathrm{W} 1 \mathrm{~W} 2) \times 100 \mathrm{~W} 1=$ weight of ash, and $\mathrm{W} 2=$ initial weight.

\subsection{Statistical Methods}

The outcomes were expressed as mean \pm SE. All data was subject to One-way ANOVA. When significant differences $(P<0.05)$ were found, the Duncan test was used to measure the group means. SPSS V.20 was used to conduct the statistical analyses.

\section{Results and Discussion}

\subsection{Growth performance}

Table 2 presents the findings of the feeding experiment. No mortality occurred during the study. All fish grew normally and no specific sign of the disease was observed. The final average weight after a trial of 10 weeks in Cyprinus carpio in control and treated ponds were recorded as $149.78 \pm 0.45,151.91 \pm 0.17$, $150.69 \pm 0.93,151.55 \pm 0.82$ and $162.59 \pm 0.97 \mathrm{~g}$ respectively, the highest values of weight gain were observed in treatment five $(20 \%$ Lentil seed). The daily weight gain, relative growth rate and specific growth rate of the $C$. carpio were significantly $(P<0.05)$ affected by feeding fish with lentil seed. Treatment five $(20 \%$ lentil seed) achieved the best results in terms of growth performance, according to the findings of this research, as indicated in table 2 .

\subsection{Feed utilization}

Nutritional indices such as the feed conversion ratio (FCR), feed efficiency ratio (FER), and protein efficiency ratio (PER) was shown in the tables 3 . Fish feeding on a diet containing $20 \%$ lentil seed (T5) had a better

Table 2. Effect of fishmeal partial replacement with five levels of lentil seed on growth performance of $C$. carpio.

\begin{tabular}{|c|c|c|c|c|c|c|c|}
\hline Treatments & $\begin{array}{l}\text { Initial Wt. } \\
(\mathrm{g})\end{array}$ & Final Wt. (g) & Wt. gain (g) & $\begin{array}{l}\text { Daily WG } \\
\text { (g) }\end{array}$ & $\begin{array}{c}\text { Specific } \\
\text { GR } \\
\%\end{array}$ & $\begin{array}{c}\text { Relative } \\
\text { GR } \\
\%\end{array}$ & $\begin{array}{c}\text { Survival } \\
\%\end{array}$ \\
\hline $\begin{array}{c}\mathrm{T} 1 \\
\text { Control }\end{array}$ & $\begin{array}{c}106.53^{\mathrm{a}} \\
\pm 0.43\end{array}$ & $149.78^{\mathrm{c}} \pm 0.45$ & $43.24^{c} \pm 0.14$ & $\begin{array}{l}0.62^{\mathrm{c}} \\
\pm 0.04\end{array}$ & $0.49^{c} \pm 0.03$ & $\begin{array}{c}40.59^{c} \\
\pm 0.44\end{array}$ & 100 \\
\hline $\begin{array}{l}\text { T2 5\% Lentil } \\
\text { seed }\end{array}$ & $\begin{array}{c}106.86^{\mathrm{a}} \\
\pm 0.25\end{array}$ & $151.91^{\mathrm{b}} \pm 0.17$ & $4505^{\circ}+032$ & $\begin{array}{l}0.64^{c} \\
\pm 0.03\end{array}$ & $050^{c}+001$ & $\begin{array}{l}42.16^{c} \\
\pm 0.95\end{array}$ & 100 \\
\hline $\begin{array}{c}\text { T3 10\% } \\
\text { Lentil seed }\end{array}$ & $\begin{array}{c}101.55^{\mathrm{a}} \\
\pm 0.65\end{array}$ & 150 & 3 & $\begin{array}{l}0.70^{\mathrm{b}} \\
\pm 0.02\end{array}$ & 5 & $\begin{array}{l}48.39^{b} \\
\pm 0.34\end{array}$ & 100 \\
\hline $\begin{array}{l}\text { T4 15\% } \\
\text { Lentil seed }\end{array}$ & $\begin{array}{c}101.04^{a} \\
\pm 0.76\end{array}$ & $151.55^{b} \pm 0.82$ & $50.51^{b} \pm 0.33$ & $\begin{array}{l}0.72^{\mathrm{b}} \\
\pm 0.03\end{array}$ & $0.57^{b} \pm 0.04$ & $\begin{array}{l}49.99^{b} \\
\pm 0.17\end{array}$ & 100 \\
\hline $\begin{array}{c}\text { T5 20\% } \\
\text { Lentil seed }\end{array}$ & $\begin{array}{c}103.02^{\mathrm{a}} \\
\pm 0.13\end{array}$ & $162.59^{\mathrm{a}} \pm 0.97$ & $59.57^{\mathrm{a}} \pm 0.41$ & $\begin{array}{l}0.85^{a} \\
\pm 0.05\end{array}$ & $0.66^{\mathrm{a}} \pm 0.07$ & $\begin{array}{l}57.82^{\mathrm{a}} \\
\pm 0.92\end{array}$ & 100 \\
\hline
\end{tabular}

Different letters in one column mean significant differences at $\mathrm{P}<0.05$. 
Table 3. Effect of fishmeal partial replacement with five levels of lentil seed on feed utilization of $C$. carpio.

\begin{tabular}{cccc}
\hline Treatments & $\begin{array}{c}\text { Feed conversion } \\
\text { ratio } \\
\text { FCR }\end{array}$ & $\begin{array}{c}\text { Feed efficiency ratio } \\
\text { FER }\end{array}$ & $\begin{array}{c}\text { Protein efficiency ratio } \\
\text { PER }\end{array}$ \\
\hline $\begin{array}{c}\text { T1 } \\
\text { Control } \\
\text { T2 }\end{array}$ & $4.28^{\mathrm{a}} \pm 0.05$ & $0.24^{\mathrm{c}} \pm 0.04$ & $1.52^{\mathrm{c}} \pm 0.02$ \\
$\begin{array}{c}5 \% \text { Lentil seed } \\
\text { T3 }\end{array}$ & $3.35^{\mathrm{c}} \pm 0.1$ & $0.3^{\mathrm{b}} \pm 0.02$ & $1.57^{\mathrm{c}} \pm 0.02$ \\
$10 \%$ Lentil seed \\
$\begin{array}{c}\text { T4 } \\
15 \% \text { Lentil seed } \\
\text { T5 }\end{array}$ & $4.69^{\mathrm{a}} \pm 0.9$ & $0.22^{\mathrm{c}} \pm 0.04$ & $1.71^{\mathrm{b}} \pm 0.03$ \\
$20 \%$ Lentil seed & $3.85^{\mathrm{b}} \pm 0.02$ & $0.26^{\mathrm{c}} \pm 0.09$ & $1.79^{\mathrm{b}} \pm 0.03$ \\
\hline
\end{tabular}

Different letters in one column mean significant differences at $\mathrm{P}<0.05$.

feed conversion ratio compared to other treatments. At treatment five $(20 \%$ lentil seed), the FER and PER were significantly $(P<0.05)$ higher than the other treatments.

\subsection{Proximate Composition}

Fish fillet proximate composition such as moisture, crude protein, crude lipid and ash was shown in table (4). The highest moisture content of carp meat was in the second treatment $(5 \%$ lentil seed) $(66.61 \pm 1.21)$ without statistically significant differences $(\mathrm{P}<0.05)$ with other treatments. The results showed that the highest ratio of crud protein and lipid was in the fifth (10\% lentil seed) and fourth ( $15 \%$ lentil seed) treatment $18.83 \pm 0.72$ and $12.33 \pm 0.53$ respectively and did not differ statistically with the rest of the treatments. The findings of the study's treatment of ash content in fish meat did not show any significant $(\mathrm{P}<0.05)$ differences in the ash content of fish meat.

\subsection{Muscle ratio}

The amount of flesh weight was calculated using data on muscle ratio (weight without viscera and weight without viscera and head), and the results were shown in table (5). There were no significant differences between treatments.

Different scientists have suggested different cost-effective sources of protein for feed preparation to achieve optimal fish growth (Kaushik and Troell, 2010; Radhakrishnan et al., 2016). In fish feed, plant ingredients have a great potential to replace fishmeal, it is possible to substitute fishmeal fully or partially with plantbased protein without loss of growth efficiency (Middleton et al., 2000; Kaushik et al., 2004).

According to different studies, herbivores require considerably less protein than carnivores. Vechklang et al. (2011) noticed that O. niloticus performed better growth when $20 \%$ of the fish meal was substituted with protein from a mixture of different plant protein meals.

Table 4. Effect of fishmeal partial replacement with five levels of lentil seed on proximate analyses of $C$. carpio.

\begin{tabular}{ccccc}
\hline Treatments & Moisture \% & Crude Protein \% & Crude lipid \% & Ash \% \\
\hline $\begin{array}{c}\text { T1 } \\
\text { Control } \\
\text { T2 }\end{array}$ & $66.54^{\mathrm{a}} \pm 0.39$ & $17.10^{\mathrm{a}} \pm 0.04$ & $12.10^{\mathrm{a}} \pm 0.06$ & $1.60^{\mathrm{a}} \pm 0.27$ \\
$\begin{array}{c}5 \% \text { Lentil seed } \\
\text { T3 }\end{array}$ & $66.61^{\mathrm{a}} \pm 1.21$ & $17.67^{\mathrm{a}} \pm 0.29$ & $12.05^{\mathrm{a}} \pm 0.52$ & $2.83^{\mathrm{a}} \pm 0.28$ \\
$\begin{array}{c}10 \% \text { Lentil seed } \\
\text { T4 }\end{array}$ & $65.67^{\mathrm{a}} \pm 0.49$ & $18.69^{\mathrm{a}} \pm 0.42$ & $12.32^{\mathrm{a}} \pm 0.05$ & $2.83^{\mathrm{a}} \pm 0.26$ \\
$\begin{array}{c}15 \% \text { Lentil seed } \\
\text { T5 }\end{array}$ & $66.11^{\mathrm{a}} \pm 0.59$ & $18.35^{\mathrm{a}} \pm 0.89$ & $12.33^{\mathrm{a}} \pm 0.53$ & $2.65^{\mathrm{a}} \pm 0.24$ \\
$20 \%$ Lentil seed & $65.10^{\mathrm{a}} \pm 0.24$ & $18.83^{\mathrm{a}} \pm 0.72$ & $12.26^{\mathrm{a}} \pm 0.18$ & $2.59^{\mathrm{a}} \pm 0.32$ \\
\hline
\end{tabular}

Different letters in one column mean significant differences at $\mathrm{P}<0.05$. 
Table 5. Effect of fishmeal partial replacement with five levels of lentil seed on meat indices of $C$. carpio.

\begin{tabular}{|c|c|c|}
\hline Treatments & $\begin{array}{c}\text { Weight of fish meat without } \\
\text { head Index (g) }\end{array}$ & $\begin{array}{c}\text { Weight of fish meat without head } \\
\text { \& viscera Index (g) }\end{array}$ \\
\hline $\begin{array}{c}\mathrm{T} 1 \\
\text { Control }\end{array}$ & $84.61^{a} \pm 0.59$ & $57.36^{a} \pm 2.31$ \\
\hline $\begin{array}{c}\text { T2 } \\
5 \% \text { Lentil seed }\end{array}$ & $83.83^{a} \pm 1.71$ & $53.93^{a} \pm 1.31$ \\
\hline $\begin{array}{l}\text { T3 } \\
10 \% \text { Lentil seed }\end{array}$ & $87.81^{a} \pm 0.66$ & $54.89^{a} \pm 0.86$ \\
\hline $\begin{array}{c}\text { T4 } \\
15 \% \text { Lentil seed }\end{array}$ & $85.90^{\mathrm{a}} \pm 1.62$ & $51.21^{\mathrm{a}} \pm 1.41$ \\
\hline $\begin{array}{c}\text { T5 } \\
20 \% \text { Lentil seed }\end{array}$ & $84.70^{a} \pm 1.36$ & $55.04^{\mathrm{a}} \pm 3.13$ \\
\hline
\end{tabular}

Different letters in one column mean significant differences at $\mathrm{P}<0.05$.

Guo (2016) found that up to $300 \mathrm{~g} / \mathrm{kg}$ of pea and lentil starch can be used in Nile tilapia diets without impacting growth efficiency. Also, fish fed with lentil starch as a source of carbohydrates had relatively higher growth performance than those fed from other sources of starch, even though no significant difference was observed. Zhou and Yue (2010) and Mahboob (2014), stated that fish meal could be successfully replaced with other plant protein source in $O$. niloticus diet. Our findings were consistent with these results.

Contrary to our findings, some studies have reported a reduction in the growth output of fish fed diets when a fish meal was supplemented by alternative sources of protein other than soybean (Bullerwell et al., 2016; Anderson et al., 2018) maybe because alternative plant proteins have lower profiles of amino acids than the ingredients they substitute (Reigh, 2008). Kasiga and Brown (2019) were also found to decrease weight gain with increased carinata (Brassica carinata) meal replacement of fish meal. The final weight of the control group at the end of the Yürüten Özdemir and Yıldız (2019) experiment was higher than the other experimental fish groups when they substituted fish meal with red lentil meal (RLM) as an alternative source of plant protein in juvenile rainbow trout diets. The discrepancies between these findings can be linked to the source of protein, the quality and processing, the species and size of fish, the experimental time and the cultivation systems.

The efficiency of feed utilization is well known to be influenced by the content of dietary protein (Sotolu and Faturoti, 2011). Dietary protein intake and its transformation into fish weight gain are related to FCR and PER (Koumi et al., 2009). In the T5 (LS20) in this research, the lowest FCR and the highest PER were obtained and varied significantly $(P<0.05)$ from those of all other groups. Relatively good (lower) FCR, FER and PER were obtained by Luo et al. (2011) in the case of mitten crab Eriocheir sinensis fed a diet containing $7.5 \%$ soybean meal and $7.5 \%$ rapeseed meal, also Al-Thobaiti et al. (2018) found that replacing fish meal with a mixture of different plant protein meals can observe better feed consumption in Nile tilapia Oreochromis niloticus. Combined, these results suggest that the diet of plant protein caused related effects on feed parameters and nutrient utilization in common carp, mitten crab and Nile tilapia

The results of this finding are contradictory to those found in a recent study by Özdemir and Yıldız (2019), in which replacing fish meal with red lentil meal has no effect on nutritional indices in juvenile rainbow trout. Jiang et al. (2013) stated that PER and FER were steadily reduced and FCR increased by increasing the replacement of fish meal with cottonseed in Chinese mitten crab Eriocheir sinensis. Poor palatability, a deficit of one or more essential amino acids and a less apparent coefficient of digestibility has been recorded for plant-based diets, which may have impacts relating to reduced feed intake (Tusche et al., 2012; Gatlin et al., 2007; Bautista-Teruel et al., 2003).

Various and contrary effects have been published in the literature regarding the impact of plant protein sources on body composition in cultured fish. In this experiment, the chemical composition of the whole carcass was not affected by the different dietary treatments, which is in line with the findings of Salman and Alkhafaji (2020), who stated that there was no effect of lentils or phytase on the body composition of common carp. Furthermore, Acar and Türker (2018) noted that when a fish meal was substituted with a peanut meal, no significant differences were observed in terms of fillet proximate compositions of rainbow trout. In other fish species, similar findings have been shown when they were using sources of plant 
protein, such as siberian sturgeon Acipenser baerii (Yun et al. 2014), large yellow croaker Larimichthys crocea (Zhang et al. 2016), red drum Sciaenops ocellatus (Minjarez-Osorio et al. 2016), grass carp Ctenopharyngodon idella (Köprücü and Sertel, 2012) and turbot Psetta maxima (Bonaldo et al. 2011).

Contradictory to the results of our, Cabral et al. (2013) found that up to $75 \%$ of fish meal replacement by plant protein sources can affect whole-body lipid in Senegalese sole. According to another study conducted by Yürüten Özdemir and Yıldız (2019), with a rise in red lentil meal RLM percentages in diets, crude protein amount of whole-body fillets steadily decreased.

There are several reports in the literature on the assessment of plant proteins as potential dietary feed ingredients for various fishes, but there are only a few reports on their impact on meat indices in fish. Abdulrahman et al. (2020) showed that there were no adverse effects on the muscle ratio of fish when adding chlorella microalgae and germinated barley powder to the diet of common carp, and this agrees with recent findings. However, Abdulrahman (2014) found an improvement in fish meat indices of $C$. carpio when replacing fishmeal with Spirulina spp. Ahmed et al. (2017) noted also that the use of date palm seed powder in the common carp diet had a negative effect on meat indices.

\section{Conclusions}

In this study, the best performance of common carp feeding on a feed prepared by replacing 20 percent of the fish meal diet with plant sources (lentil seed) was achieved in growth and feed utilization. It was concluded that the lentil seed can be used in common carp feed up to $20 \%$ replacing it with fish meal. In addition to achieving better growth output in C. carpio, the substitution of fish meal with local plant sources would also be advantageous in lowering production costs, thus increasing net profit.

\section{References}

Abdulrahman, N.M. 2014. Effect of replacing fishmeal with Spirulina spp. on carcass chemical composition of common carp Cyprinus carpio L. Iraqi Journal of Veterinary Science, 28 (2): 67-70.

Abdulrahman, N.M., Sleman, H.D., Muhammed Ramzi, D.O., Hama-Salih, H.A. 2020. Effect of Chlorella microalgae and germinated barley powder on performance, some health indices, and meat hygiene parameters of common carp (Cyprinus carpio). Basrah Journal of Veterinary Research, 19 (3): 218231. Proceeding of the 17th International Conference. College of Veterinary Medicine. University of Basrah. Iraq.

Acar, Ü., Türker, A. 2018. The Effects of Using Peanut Meal in Rainbow Trout (Oncorhynchus mykiss) Diets on the Growth Performance and Some Blood Parameters. Aquaculture Studies, 18 (2): 79-87.

Ahmed, V.M., Abdulrahman, N.M., HamaAmeen, S.A., Hassan, B.R., Abbas, A.K., Hussen, B.A., Hamad, I.Sh., Karem, S.A., Aziz, K.M. 2017. Impacts of Date Palm Seeds (Phoenix dactyliferous L.) on Growth Indices and Nutrient Utilization of Common Carp Cyprinus carpio L. Journal of Agricultural Science and Technology B, 7: 280-284.

Al-Thobaitia, A., Al-Ghanima, K., Ahmeda, Z., Sulimana, E.M., Mahbooba, S. 2018. Impact of replacing fish meal by a mixture of different plant protein sources on the growth performance in Nile Tilapia (Oreochromis niloticus L.) diets. Brazilian Journal of Biology, 78 (3): 525-534.

Anderson, D.M., MacPherson, M.J., Collins, S.A., Maclsaac, P.F. 2018. Yellow and brown seeded canola Brassica napus, camelina Camelina sativa and Ethiopian mustard (Brassica carinata) in practical diets for rainbow trout (Oncorhynchus mykiss) fingerlings. Journal of Applied Aquaculture, 30 (2): 187-195.

AOAC. Official methods of analysis. 17-th ed. 2005. Washington, DC : Association of Official Analytical Chemists, pp. 20002200.

Bautista-Teruel, M.N., Fermin, A.C., Koshio, S.S. 2003. Diet development and evaluation for juvenile abalone, Haliotis asinina: animal and plant protein sources. Aquaculture, 219 (1): 645-653.

Bhatty, R.S. 1988. Composition and quality of lentil (Lens culinaris Medik): A review. 
Canadian Institute of Food Science and Technology Journal, 21: 144-160.

Bonaldo, A., Parma, L., Mandrioli, L., Sirri, R., Fontanillas, R., Badiani, A., Gatta, P.P. 2011. Increasing dietary plant proteins affects growth performance and ammonia excretion but not digestibility and gut histology in turbot (Psetta maxima) juveniles. Aquaculture, 318: 101-108.

Brown, M. E. 1957.Experimental Studies of Growth. In: Brown, M. E. (ed.) Physiology of Fishes. Vol. I. Academic Press, New York, 361-400.

Bullerwell, C.N., Collins, S.A., Lall, S.P., Anderson, D.M. 2016. Growth performance, proximate and histological analysis of rainbow trout fed diets containing Camelina sativa seeds, meal (high-oil and solvent-extracted) and oil. Aquaculture, 452: 342-350.

Cabral, E.M., Fernandes, T.J., Campos, S.D., Castro-Cunha, M., Oliveira, MB, Cunha, L.M., Valente, L.M.P. 2013. Replacement of fish meal by plant protein sources up to $75 \%$ induces good growth performance without affecting flesh quality in on growing Senegalese sole. Aquaculture, 380: 130-138.

FAO 2010. The State of World Fisheries and Aquaculture (SOFIA) FAO Fisheries and Aquaculture Department Food and Agriculture Organization of the United Nations Rome, Italy.

Folch, J., Lees, M., Sloane-Stanley, G.H. 1957. A simple method for the isolation and purification of total lipids from animal tissues. Journal of Biology \& Chemistry, 226: 497-507.

Gajardo, K., Jaramillo-Torres, A., Kortner, T.M., Merrifield, D.L., Tinsley, J., Bakke, A.M., Krogdahl, Å. 2017. Alternative protein sources in the diet modulate microbiota and functionality in the distal intestine of Atlantic salmon (Salmo salar). Applied and environmental microbiology, 83(5): 1-16.

Gatlin, D.M., Barrows, F.T., Brown, P., Dabrowski, K., Gaylord, T.G., Hardy, R.W., Herman, E. , Hu, G., Krogdahl,
A., Nelson, R., Overturf, K., Rust, M., Sealey, W., Skonberg, D., Souza, E.J., Stone, D., Wilson, R., Wurtele, E. 2007. Expanding the utilization of sustainable plant products in aquafeeds: A review. Aquaculture Research, 38 (6): 551-579.

Guo, Y. 2016. Determination of the effects of corn, pea, lentil, and faba bean starches on the digestibility, growth performance, and glycemic indices in Nile tilapia (Oreochromis niloticus). Master thesis, college of graduate studies and research, university of Saskatchewan, Saskatoon.

Hemre, G.l., Mommsen, T.P., Krogdahl, A. 2002. Carbohydrates in fish nutrition: effects of growth, glucose metabolism and hepatic enzymes. Aquaculture Nutrient, 8 (3): 175-194.

Hertrampf, J.W., Piedad-Pascual, F. 2012. Handbook on ingredients for aquaculture feeds. Springer Netherlands, 573pp.

Jiang, H.B., Chen, L.Q., Qin, J.G., Gao, L.J., Li, E.C., Yu, N., Sun, Sh.M., Jiang, X.Q. 2013. Partial or complete substitution of fish meal with soybean meal and cottonseed meal in Chinese mitten crab Eriocheir sinensis diets. Aquaculture International, 21: 617-628.

Kasiga, T., Brown, M.L. 2019. Replacement of fishmeal with processed carinata (Brassica carinata) seed meal in low animal protein diets of rainbow trout (Oncorhynchus mykiss), Aquaculture Nutrition, 25 (4): 959-969.

Kaushik, S., Troell, M. 2010. Taking the fish-in fish-out ratio a step further. Aquaculture Europe, 35 (1): 15-17.

Kaushik, S.J., Covès, D., Dutto, G., Blanc, D. 2004. Almost total replacement of fishmeal by plant protein sources in the diet of a marine teleost, the European seabass, Dicentrarchus labrax. Aquaculture, 230: 391- 404.

Köprücü, K., Sertel, E. 2012. The effects of less-expensive plant protein sources replaced with soybean meal in the juvenile diet of grass carp (Ctenopharyngodon idella): growth, nutrient utilization and body 
composition. Aquaculture international, 20 (3): 399-412.

Koumi, A.R., Atse, B.C., Kouame, L.P. 2009. Utilization of soya protein as an alternative protein source in Oreochromis niloticus diet: Growth performance, feed utilization, proximate composition and organoleptic characteristics. African Journal of Biotechnology, 8 (1): 091-097.

Lagler. KF.1956. Fresh water Fishery Biology. W.C. Brown Company; Dubuque; IA; USA; pp. 131-135: 159-166.

Luo, Z., Li, X.D., Wang, W.M., Tan, X.Y., Liu, X. 2011. Partial replacement of fish meal by a mixture of soybean meal and rapeseed meal in practical diets for juvenile Chinese mitten crab Eriocheir sinensis: effects on growth performance and in vivo digestibility. Aquaculture Research, 42 (11): 1616-1622.

Mahboob, S. 2014. Replacing fish meal with a blend of alternative plant proteins and its effect on the growth performance of Catla catla and Hypophthalmichthys molitrix. Pakistan Journal of Zoology, 46 (3): 747-752.

Middleton, J.R., Kandaswami, C., Theoharides, T.C. 2000. The Effects of Plant Flavonoids on Mammalian Cells: Implications for Inflammation, Heart Disease, and Cancer. Pharmacological reviews, 52 (4): 673-751.

Minjarez-Osorio, C., Castillo-Alvarado, S., Gatlin, D.M., González-Félix, M.L., Perez-Velazquez, M., Rossi, W. 2016. Plant protein sources in the diets of the sciaenids red drum (Sciaenops ocellatus) and shortfin corvina (Cynoscion parvipinnis): A comparative study. Aquaculture, 453: 122-129.

NRC. National Research Council 1993. Nutrition requirements of fish. Nat. Acad. Press, Washington: 174 pp.

Radhakrishnan, S., Bhavan, P.S., Seenivasan, C., Muralissankar, T. 2016. Impact of fishmeal replacement with Arthrospira platensis on growth performance, body composition and digestive enzyme activities of the freshwater prawn,
Macrobrachium Aquaculture Research, 3: 35-44.

rosenbergii.

Rahman, M. M., Verdegem, M. C.J., Nagelkerke, L.A.J., Wahab, M.A., Verreth, J.A.J. 2008. Swimming, grazing and social behaviour of rohu Labeo rohita (Hamilton) and common carp Cyprinus carpio (L.) in tanks under fed and non-fed conditions. Applied Animal Behavior Science, 113 (1-3): 255-264.

Reigh, R.C. 2008. Underutilized and unconventional plant protein supplements in feeds for finfish. In: Alternative Protein Sources in Aquaculture Diets (ed. by C. Lim, C.D. Webster \& C. Lee. The Haworth Press, New York, NY, USA. ), pp. 459-467

Salman, A.H., Alkhafaji, KH.A. 2020. Use of treated lentil lens culinaris with phytase enzyme in diets of common carp cyprinus carpio. Plant Archives, 20 (2): 941-944

Shepherd, C.J., Monroig, O., Tocher, D.R. 2017. Future availability of raw materials for salmon feeds and supply chain implications: The case of Scottish farmed salmon. Aquaculture, 467: 4962

Sotolu, A.O., Faturoti, E.O. 2011. Growth performance and hematological effects of varying dietary processed Leucaena leucocephala seed meal in Clarias gariepinus (burchell, 1822) juveniles. Africa Journal of food agriculture nutrition and development, 11 (1): 4546-4557.

Turchini, G.M., Trushenski, J.T., Glencross, B.D. 2019. Thoughts for the future of aquaculture nutrition: realigning perspectives to reflect contemporary issues related to judicious use of marine resources in aquafeeds. North American Journal of Aquaculture 81: 13-39.

Tusche, K., Arning, S., Wuertz, S., Susenbeth, A., Schulz, C. 2012. Wheat gluten and potato protein concentrate - Promising protein sources for organic farming of rainbow trout (Oncorhynchus mykiss). Aquaculture, 344-349: 120-125. 
Uten, F. 1978. Standard methods and terminology in finfish nutrition. Pro. World Smp, Finfish Nutrition and Technology, 11: 20-23.

Vechklang, K., Boonanuntanasarn, S., Ponchunchoovong, S., Pirarat, N., Wanapu, C. 2011. The potential for rice wine residual as an alternative protein source in a practical diet for Nile Tilapia (Oreochromis niloticus) at the juvenile stage. Aquaculture Nutrition, 17 (6): 685-694.

Yun, B., Xue, M., Wang, J., Sheng, H., Zheng, Y., Wu, X. 2014. Fishmeal can be totally replaced by plant protein blend at two protein levels in diets of juvenile Siberian sturgeon, Acipenser baerii Brandt. Aquaculture nutrition, 20 (1): 69-78.

Yürüten Özdemir, K., Yıldız, M. 2019. Effects of Dietary Fish Meal Replacement by Red
Lentil Meal on Growth and Amino Acid Composition of Rainbow Trout (Oncorhynchus mykiss). Alnteri Journal of Agriculture Sciences, 34 (2): 194203.

Zhang, H., Yi, L., Sun, R., Zhou, H., Xu, W. 2016. Effects of dietary citric acid on growth performance, mineral status and intestinal digestive enzyme activities of large yellow croaker Larimichthys crocea (Richardson, 1846) fed high plant protein diets. Aquaculture, 453: 147-153.

Zhou, Q.C., Yue, Y.R. 2010. Effect of replacing soybean meal with canola meal on growth, feed utilization and haematological indices of juvenile hybrid tilapia, Oreochromis niloticus $\times$ Oreochromis aureus. Aquaculture Research, 41 (7): 982-990. 